\title{
Factors influencing early discontinuation in a 3-month group weight loss program
}

\author{
Tomasz Wikarek ${ }^{1}$, Barbara Zahorska-Markiewicz ${ }^{2}$, Wojciech Gruszka ${ }^{1}$, Piotr Dąbrowski ${ }^{1}$, \\ Kamil Barański ${ }^{3,4}$, Magdalena Olszanecka-Glinianowicz ${ }^{1}$ \\ ${ }^{1}$ Health Promotion and Obesity Management Unit, Department of Pathophysiology, Medical University of Silesia, \\ Katowice, Poland \\ 2Metabolic Management Clinic "WAGA", Katowice, Poland \\ ${ }^{3}$ Pathophysiology Unit, Department of Pathophysiology, Medical University of Silesia, Katowice, Poland \\ ${ }^{4}$ Department of Hygiene and Epidemiology, Medical University of Silesia, Katowice, Poland
}

\begin{abstract}
Introduction: Over the past several decades, obesity rates have been dramatically increasing, especially in highly developed countries. Epidemiological data indicate that currently about $50 \%$ of the population is suffering from overweight or obesity. The aim of the study was to assess the external factors resulting in early resignation from a 3-month group weight loss program.
\end{abstract}

Material and methods: The study group involved 217 subjects starting a 3-month weight loss program. The number of patients who resigned from the program was counted after each session. At the end of the program all the patients were asked to complete a questionnaire including questions about their level of education, marital status, working hours, distance from their place of residence, costs of travel and the level of satisfaction with the program and its effects.

Results: $46 \%$ of subjects completed the program and $56.2 \%$ responded to the questionnaire. After the first meeting, dropouts were more frequent among participants who lived far away from the place where the sessions were held (above $23.6 \pm 14.6 \mathrm{~km}$ ) and who had the highest costs of transportation (mean 6.1 euro). Relative risk of early discontinuation was 3.32, $p<0.001$ for distance from the place of residence above $21.2 \mathrm{~km}, 3.60$, $p<0.05$ for cost of transportation over 3.1 euro and 7.23 (2.08-25.38), $p=0.002$ for monthly income per household member below 234 euro. Other study factors did not influence program discontinuation.

Conclusions: Low incomes, distance from the place of residence and costs of transportation are important factors of early discontinuation of 3-month group weight loss programs in Poland.

Key words: obesity, group weight loss program, discontinuation, economic factors.

\section{Introduction}

Over the past several decades, obesity rates have been dramatically increasing, especially in highly developed countries. Epidemiological data indicate that currently about $50 \%$ of the population is suffering from overweight or obesity [1]. Almost one-third of adult Canadians are at increased risk of disability, diseases and premature death relating to obesity [2]. In the United States, health costs of overweight and obesity and obesity-related diseases are enormously high. The direct costs associated with obesity in 2004 were estimated at $5.7 \%$ of the National Health Expenditure in the United States [3]. It is expected that health-care costs attributable to obesity/overweight will double every decade, accounting for $16-18 \%$ of total US health-care costs in 2030 [4]. In Poland, the prevalence of obesity in a population aged $20-74$ years is $20.2 \%$ in women and $20.6 \%$ in men [5] and among subjects aged 65 years and over $-39.0 \%$ in women and $25.6 \%$ in men [6]. It is estimated that therapy of obesity and its compli-

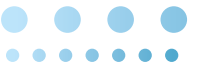

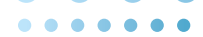


cations in Poland is about $21 \%$ of the health care budget [7]. It is anticipated that the effective prevention and treatment of obesity could reduce the overall costs of health care [2].

Effective treatment of obesity, like the management of chronic diseases, requires long-term motivation, following strict dietary guidelines and regular physical activity. Every patient must permanently change his/her previous lifestyle [8].

Currently, there are a large variety of weight loss programs on obesity management. One of them is a 3-month group weight loss program, based on group education and counseling. A lot of research confirms high efficacy of this type of therapy. The best results are obtained by an interdisciplinary approach, consisting of a diet, physical exercises and group education with specialists $[9,10]$. Group formula of the meetings assumes a simultaneous double support system: professional counseling as well as physiological therapy and other members' support [9]. However, participation in a group weight loss program depends on a variety of medical, demographic, social and personal factors. Many participants starting the weight loss program resign from further therapy after a short time. It could be caused by external factors, such as: lack of support from families and friends, lack of time, long distance from the place of residence, costs of transportation or internal factors, such as: depression, lack of motivation or self-discipline [11]. Comprehension of these factors can help to modify the strategy of behavioral therapy on obesity and health promotion programs.
The aim of the study was to assess the external factors resulting in early resignation from a 3-month group weight loss program.

\section{Material and methods}

The study group involved 217 subjects (175 women and 42 men) starting a 3-month group weight loss program (Table 1). Participation in this program was complimentary.

The 3-month group weight loss program is an original program designed by Zahorska-Markiewicz in 1992 [12]. It included sessions with a doctor, a psychologist, a dietician and a physiotherapist. The whole program consisted of seven 2-hour sessions every second week. During the first hour of the session patients were receiving instructions on behavioral, dietary and physical exercise methods of weight control. In the second hour the subjects participated in a group psychotherapy using cognitive, behavioral and autohypnosis techniques.

Weight and height were measured and BMI was calculated at the beginning and measurements of weight were performed before each meeting. The number of patients resigning from this program was counted after each session.

Two months after finishing the therapy each subject who started the program was sent a questionnaire concerning the level of education, marital status, working hours, monthly inocme per household member, costs of transportation, level of satisfaction with the therapy and its effects.

Table 1. Patient characteristics

\begin{tabular}{|c|c|c|c|c|c|c|c|}
\hline & Starting & $\begin{array}{l}\text { Finished } \\
\text { after } 1^{\text {st }} \\
\text { meeting }\end{array}$ & $\begin{array}{l}\text { Finished } \\
\text { after } 2^{\text {nd }} \\
\text { meeting }\end{array}$ & $\begin{array}{l}\text { Finished } \\
\text { after } 3^{\text {rd }} \\
\text { meeting }\end{array}$ & $\begin{array}{l}\text { Finished } \\
\text { after } 4^{\text {th }} \\
\text { meeting }\end{array}$ & $\begin{array}{l}\text { Finished } \\
\text { after } 5^{\text {th }} \\
\text { meeting }\end{array}$ & Finished \\
\hline$N$ & 217 & $23(10.6 \%)$ & 31 (14.3\%) & $26(12 \%)$ & $12(5.5 \%)$ & 25 (11.5\%) & 100 (46.1\%) \\
\hline Age (years) & $45.8 \pm 14.1$ & $44.2 \pm 14.3$ & $42.3 \pm 14.8$ & $43.6 \pm 14.2$ & $41.6 \pm 14.3$ & $44.7 \pm 15.3$ & $47.6 \pm 12.7$ \\
\hline Body mass (kg) & $98.6 \pm 18.4$ & $97.7 \pm 21.5$ & $100.4 \pm 17.0$ & $102.0 \pm 15.7$ & $95.2 \pm 26.8$ & $97.9 \pm 19.8$ & $97.8 \pm 17.7$ \\
\hline $\mathrm{BMI}\left(\mathrm{kg} / \mathrm{m}^{2}\right)$ & $36.8 \pm 7.4$ & $36.4 \pm 7.3$ & $36.7 \pm 4.8$ & $38.6 \pm 5.6$ & $36.7 \pm 11.1$ & $36.4 \pm 6.3$ & $36.1 \pm 5.3$ \\
\hline $\begin{array}{l}\text { Distance from the } \\
\text { place of residence }(\mathrm{km})\end{array}$ & $15.5 \pm 11.0$ & $23.6 \pm 14.6^{*}$ & $13.3 \pm 9.4$ & $15.0 \pm 9.4$ & $15.5 \pm 9.5$ & $14.9 \pm 10.1$ & $14.7 \pm 10.8$ \\
\hline $\begin{array}{l}\text { Time of transportation } \\
\text { (min) }\end{array}$ & $78 \pm 48$ & $95 \pm 52$ & $70 \pm 27$ & $97 \pm 46$ & $64 \pm 47$ & $51 \pm 16$ & $80 \pm 56$ \\
\hline $\begin{array}{l}\text { Cost of transport } \\
\text { (euro) }\end{array}$ & $3.4 \pm 2.8$ & $6.1 \pm 5.5^{\star \star}$ & $3.2 \pm 2.4$ & $1.8 \pm 1.3$ & $1.0 \pm 1.4$ & $2.1 \pm 1.4$ & $2.8 \pm 2.3$ \\
\hline $\begin{array}{l}\text { Monthly income per } \\
\text { household member } \\
\text { (euro) }\end{array}$ & $394 \pm 267$ & $257 \pm 114^{*}$ & $370 \pm 193$ & $325 \pm 140$ & $250 \pm 63^{*}$ & $373 \pm 149$ & $491 \pm 345$ \\
\hline $\begin{array}{l}\text { Subjects who } \\
\text { answered to the } \\
\text { questionnaire [\%] }\end{array}$ & & 56.5 & 51.6 & 51.7 & 41.7 & 68.0 & 56.0 \\
\hline
\end{tabular}

${ }^{*} p<0.05,{ }^{* *} p<0.005$ 
The distances from the place of residence to the center were calculated based on addresses from the medical database. All distances were calculated using an Internet map.

\section{Statistical analysis}

All statistical analyses were performed using Statistica 8.0 software. The results are presented as means with standard deviations or percentage. The $\chi^{2}$ test was used for comparison of quality variables. The Mann-Whitney $U$ test was used for comparison of numerical variables such as distance from the place of residence and costs of transportation. ROC analysis was applied to assess the values of the distance from the place of residence, cost and time of transportation and monthly income per household member characteristic of patients who discontinued the program early. A relative risk (RR) of early discontinuation for values established by ROC analysis was calculated based on logistic regression. The results were considered statistically significant with a $p$ value of less than 0.05 .

\section{Results}

One-hundred out of 217 (46\%) participants completed the program and $122(56.2 \%)$ answered to the questionnaire, including more than $50 \%$ of subjects who discontinued the therapy. The number of subjects who resigned after subsequent meetings and who answered to the questionnaire are presented in Table 1. The highest number of patients resigned after the $2^{\text {nd }}$ meeting $(n=31$; $26.5 \%$, $)\left(\chi^{2}=3.89 ; p<0.05\right)$.

As described above, the distance from the place of residence to the program center was calculated using an Internet map for all subjects starting the program. Subjects who resigned after the first meeting had the longest distance from the place of residence $(23.6 \pm 14.6 \mathrm{~km})$ and

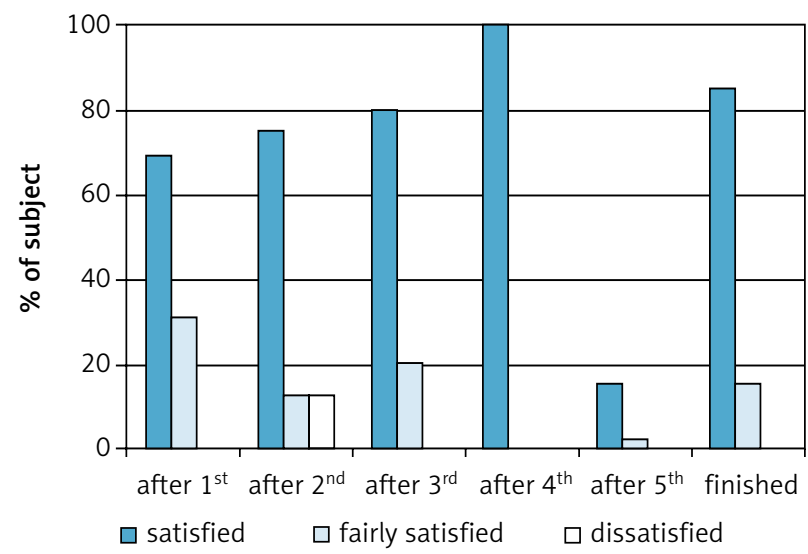

Figure 1. The level of satisfaction with the program at the time of discontinuation 2.3-times higher declared costs of transportation than the remaining subgroups (Table 1 ).

The distance above $21.2 \mathrm{~km}$ and the costs over 3.1 euro, but not the time of transportation, predicted early program discontinuation with the sensitivity of $56.5 \%$ and $61.5 \%$, and specificity of $82.0 \%$ and $76.3 \%$, respectively. Moreover, the obese with a monthly income below 234 euro per household member were prone to early discontinuation of the program (sensitivity $72.7 \%$ and specificity $79.1 \%)$. Relative risk of early discontinuation was 3.32 (2.07-5.34), $p<0.001$ for the distance from the place of residence above $21.2 \mathrm{~km}, 3.60$ (1.04-1.48), $p<0.05$ for costs of transportation over 3.1 euro and 7.23 (2.08-25.38), $p=0.002$ for monthly income per household member below 234 euro.

Factors like gender, marital status, level of education as well as working hours of participants did not influence the time of resignation from the program.

$84.5 \%$ of subjects who completed the questionnaire were pleased with the program content and $74.4 \%$ were satisfied with its effects. $13.9 \%$ of subjects were fairly satisfied with the program and $16.6 \%$ with its results. Only $1.6 \%$ were dissatisfied with the program and $9.0 \%$ with its effects. It is worth noting that subjects who completed the program were more dissatisfied with the effects.

The level of satisfaction with the program and its results and the time of resignation are presented in Figures 1 and 2, respectively. The level of satisfaction did not influence the time of participation in our program.

\section{Discussion}

This study revealed that economic aspects of participation in a 3-month group weight loss program are important for maintaining obesity therapy. These aspects e.g. costs of transportation and monthly income per household member are more significant than time spent on traveling.

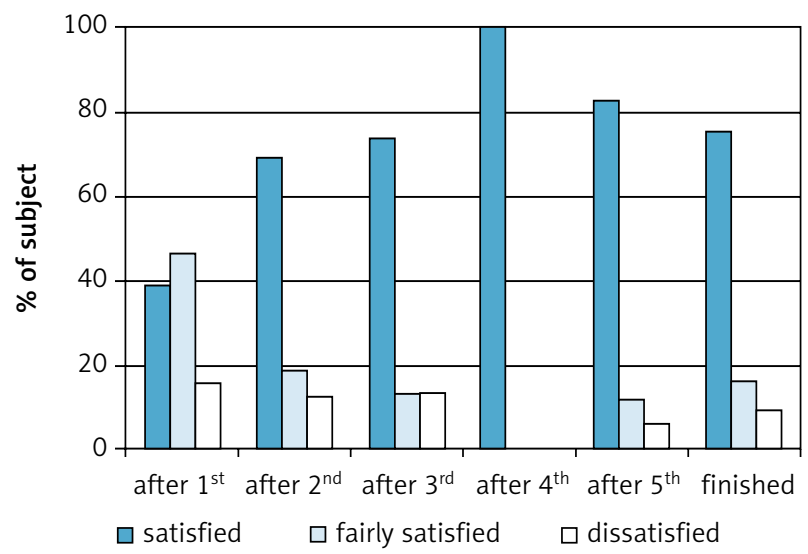

Figure 2. The level of satisfaction with the effects and time of resignation 
In our study, $45 \%$ of participants completed the therapy. The results are acceptable for such an intensive program. Other authors demonstrate about $50 \%$ of subjects completing weight loss programs with marked diversity in dropout rates between the centers $[11,13]$. However, it was described that even $75 \%$ of participants completed two-year weight loss therapies [14]. Yet, no data for centers in Poland have been published.

In the early 1990s, Barbara Zahorska-Markiewicz organized in Katowice the first multidisciplinary centre for obesity management in Poland. The center has provided two sorts of obesity therapy: individual and group management. The 3-month group weight loss program has been organized twice a year in the spring and in the autumn. More than 5000 obese subjects have participated in group management since 1998. The present study assesses only the subgroup participating in one autumn edition of this program.

Recently published studies have revealed that the spectrum of reasons for resignation from group weight loss therapy were heterogeneous. The highest number of patients resigns in the first stages of therapy, while the frequency of dropouts later on decreased $[11,15]$. In the present study we observed a similar tendency because the highest number of patients resigned after the second meeting.

Dalle Grave et al. [11] showed a high number of dropouts of unsatisfied patients, who were expecting immediate effects in the first stages of therapy. This observation was not confirmed in our population, the dropout rate was considerable regardless of a high level of satisfaction with the program and its effects. Reliability of our satisfaction data should be taken with caution as the questionnaire was not anonymous.

Participation in group weight loss programs is related to various logistics problems, such as transportation, working hours, disorganization of family life. Our results revealed that the longer the distance from the place of residence and higher costs of transportation, the higher the risk of discontinuation of the program. The costs of transportation were more important than the time necessary to get to the center, despite the fact that the therapy was complimentary. Similar findings were also obtained by other researchers who claim that logistics was the most frequent reason for obesity treatment discontinuation (51.1\%) [16]. Living far from the obesity management center and economic factors played an important role in those cases. However, Dalle Grave et al. [11] showed results partially opposite to our results. They observed that other main reasons for resignation were work and family problems, whereas in our study, work and family problems were rarely the reasons for discontinuation. Also Ahnis et al. [17] showed that only $8 \%$ of participants discontinued therapy due to economic reasons. More important factors were younger age, psychological variables, low self-efficacy, the lack of coping skills, no gainful employment. The other study revealed that conflicts between time of sessions and other activities was the reason for $30 \%$ of discontinuations [18]. In a similar way Pott et al. observed that due to the lack of time, $11 \%$ of participants resign from the obesity program [19]. Additionally, it has also been found that sociodemographic factors, such as a lower education level, being an immigrant, lack of occupation and higher body dissatisfaction were factors explaining an increased risk of drop-out [20].

Another important factor influencing successful therapy and effects is high frequency of therapist-patient contacts (once a week) $[21,22]$. In our study the contacts were quite frequent (every second week), but the duration of the program was limited to 3 months, which might have limited the long-term efficacy.

As described above, obesity imposes an increasing burden on the health care system which grows disproportionately large for the most obese subjects [4]. It is anticipated that prevention and therapy of obesity will have major positive effects on the overall cost of health care [2]. These goals could be achieved if the management of obesity is more effective. Therefore, recognition of factors limiting the adherence to obesity management is the first step towards improving cost-effectiveness for the National Health System. Economical factors which strongly decrease the adherence should be eliminated, for instance by creating a number of specialist centers for obesity treatment closer to places of residence. The institutions responsible for planning and financing health promotion programs should take into consideration long-term aspects of obesity management. The assessment of cost-effectiveness is necessary to select the most effective models of therapy. Management of obesity by general practitioners is difficult due to time limitations and the lack of collaboration with dieticians and physiologists but their participation in this process is necessary.

\section{Conclusions}

Low incomes, the distance from the place of residence and the costs of transportation are important factors of early discontinuation of 3-month group weight loss programs in Poland. Our results emphasized the necessity of group education for obese close to their place of residence.

\section{Disclosure}

Authors report no conflict of interest. 


\section{References}

1. James WP. The epidemiology of obesity: the size of the problem. J Intern Med 2008; 263: 336-352.

2. Birmingham CL, Muller JL, Palepu A, Spinelli JJ, Anis AH. The cost of obesity in Canada. CMAJ 1999; 160: 483-488.

3. Wang Y, Beydoun MA, Liang L, Caballero B, Kumanyika SK. Will all Americans become overweight or obese? Estimating the progression and cost of the US obesity epidemic. Obesity 2008; 16 : 2323-2330.

4. Andreyeva T, Sturm R, Ringel JS. Moderate and severe obesity have large differences in health care costs. Obes Res 2004; 12: 1936-1943.

5. Biela U, Pajak A, Kaczmarczyk-Chałas K, et al. Częstość występowania nadwagi i otyłości u kobiet i mężczyzn w wieku 20-74 lat. Wyniki programu WOBASZ. Kardiol Pol 2005; 63 (6 Suppl 4): S632635 [in Polish].

6. Olszanecka-Glinianowicz M, Chudek J, Kołłajtis-Dołowy A, Milewicz A, Krzyżanowska-Świniarska B, Więcek A. Stan odżywienia i uzębienia u osób w wieku podeszłym w Polsce. In: Mosakowska M, Więcek A, Błędowski P (eds.). PolSenior - aspekty medyczne, psychologiczne, socjologiczne i ekonomiczne starzenia się ludzi w Polsce. Termedia, Poznań 2012, pp. 335-350 [in Polish].

7. Jarosz M, Rychlik E. Epidemia otyłości - jaka przyszłość nas czeka? Gastroenterol Pol 2010; 17: 47-52 [in Polish].

8. Ostrowska L, Karczewski J. Ocena wpływu wsparcia psychologicznego na redukcję masy ciała otyłych pacjentów. Wiad Lek 2002; 55: 174-182 [in Polish].

9. Bąk-Sosnowska M, Zahorska-Markiewicz B. Aspekty psychologiczne grupowego leczenia otyłości. Med Metabol 2003; 3: 73-77 [in Polish].

10. Olszanecka-Glinianowicz M, Zahorska-Markiewicz B, Skubacz M, Żurakowski A, Ziemlewska M, Żak A. Wpływ trzymiesięcznej kompleksowej kuracji odchudzającej na modyfikację zachowań żywieniowych otyłych kobiet. Wiad Lek 2002; 55: 547-552 [in Polish].

11. Dalle Grave R, Melchionda N, Calugi S, et al. Continuous care in the treatment of obesity: an observational multicentre study. I Intern Med 2005; 258: 265-273.

12. Zahorska-Markiewicz B. The weight reduction program in Poland and its distribution. In: The Round Table Meeting on Obesity Management in Central Europe. Hainer M, Kunesova M (eds.). Publishing House PANAX, Prague 1997, p. 34.

13. Wadden TA, Foster GD, Letizia KA, Stunkard AJ. A multicenter evaluation of a proprietary weight reduction program from the treatment of marked obesity. Arch Intern Med 1992; 152: 961-966.

14. Heshka S, Anderson JW, Atkinson RL, et al. Weight loss with selfhelp compared with a structured commercial program: a randomized trial. JAMA 2003; 289: 1792-1798.

15. Serdula MK, Khan LK, Dietz WH. Weight loss counseling revisited. JAMA 2003; 289: 1747-1750.

16. Avenell A, Broom J, Brown TJ, et al. Systemic review of the longterm effects and economic consequences of treatments for obesity and implications for health improvement. Health Technol Assess 2004; 8: 1-182.

17. Ahnis A, Riedl A, Steinhagen-Thiessen E, Liebl ME, Klapp FB. Psychological and sociodemographic predictors of premature discontinuation of a 1-year multimodal outpatient weight-reduction program: an attrition analysis. Patient Prefer Adherence 2012; 6: 165-177.

18. Levine DM, Ringham MR, Kalarchian AM, Wisniewski L, Marcus DM. Is family-based behavioral weight control appropriate for severe pediatric obesity? Int J Eat Disord 2001; 3: 318-328.

19. Pott W, Albayrak O, Hebebrand J, Pauli-Pott U. Treating childhood obesity: family background variables and the child's success in a weight-control intervention. Int J Eat Disord 2009; 42: 284-289.
20. Elfhag K, Rossner S. Initial weight loss is the best predictor for success in obesity treatment and sociodemographic liabilities increase risk for drop-out. Patient Educ Couns 2010; 79: 361-366.

21. Bjorvell $\mathrm{H}$, Rossner $\mathrm{S}$. A ten-year follow-up of weight change in severely obese subjects treated in a combined behavioral modification programme. Int J Obes Relat Metab Disord 1992; 16: 623-625.

22. Perri MG, Corsica JA. Improving the maintenance of weight lost in behavioral treatment of obesity. In: Handbook of Obesity Treatment. Wadden TA, Stunkard AJ (eds.). Guilford Press, New York 2002, pp. 357-379. 